tions, not constituents, of the affectional element, and the denial of our ability to imagine the latter as distinct from really experiencing it as present felt qualification of the represented content appears to the author highly important as a matter of psychological principle.

Certainly, as a matter of pure introspection, it would seem impossible for the attention to fasten on any content corresponding to the abstractions 'pleasure-pain' or 'psychic attitude.' If, as Mr. Titchener maintains, a feeling is 'properly analyzed into sense-substrate and affection,' nothing can be discovered among the objects of direct consciousness corresponding to the latter. On the other hand we can attend, as Mr. Titchener allows, to our concrete feelings. A toothache, a state of grief or terror, can be as distinctly felt as a patch of red color or a movement in the joints. And if felt, then represented as felt, with something, no doubt, of the repercussion of the original excitement. Without this the object represented is not really the same, and the experience is remembered much as a color is remembered which is not visualized; we know, that is, its name, perhaps some of its concomitants. Apart from these experiences, there is nothing in pleasure, pain and emotion for psychology to deal with: they are mere names which express, not psychological experience, but the practical value of the experiences which they qualify.

Smith College.

H. N. Gardiner.

\title{
REACTION-TIME.
}

Zur Beurtheilung der zusammengesetzten Reactionen. W. WUndT. Philos. Stud., X, 485-498. 1894 .

Beobachtungen bei zusammengesetzten Reactionen. Zweibriefiche Mittheilungen an den Herausgeber. E. KRAEPELIN und Julius MERKeL. Philos. Stud., X, 499-506. I894.

Simple Reactions. E. B. Titchener. Mind, N. S., I3, 74-8I. Jan., 1895 .

Two Points in Reaction-time Experimentation. R. Watanabe. Am. Journ. of Psychol., VI, 408-5I2. June, 1894.

The articles in the Philosophische Studien call attention to an aspect of experimental psychology sometimes overlooked-namely, the importance of the knowledge that may be derived from introspection in the course of psychological experiments. Thus Prof. Wundt states explicitiy that his theory of the development of the will, and of its relation to 'apperception,' had its origin in observations made during the course of experiments on reaction-time. He 
concludes his discussion by saying that the times measured have only an incidental interest-the real value of such experiments lies in the fact that they subject mental processes to fixed conditions, and thus make possible an exact analysis by introspection. While much can be said for this point of view, the present articles do not give conclusive testimony in its favor, as they are controversial, the introspective evidence of some observers contradicting that of others.

Wundt argues for the interpretation of sensory and motor reactions, 'perception-times,' 'discrimination-times,' 'choice-times,' and 'association-times' already given in detail in the fourth edition of the Physiologische Psychologic. Wundt is regarded as the great representative of the experimental and scientific method in psychologyand deservedly so-but he does not readily adapt himself to the scientific attitude that weighs evidence and waits for evidence. He considers it possible and desirable to pass final judgment on every question great and small. This he does with much learning and ability, but often without proper perspective. He sees the world as a panorama with himself in the centre. He forgets that a panorama, constructed from fragmentary data, holds only for the individual who constructs it-also that there is no centre of infinite space.

The experiments on sensory and motor reactions do not seem to the present writer nearly so important as they do to Wundt, nor can he admit Wundt's interpretation of the facts. When Wundt informs us that " $z u$ Versuchen uber den zeitlichen Verlauf psychischer Vorgänge ist nun von vornherein nur ein Beobachter fähig, der im stande ist, willkürlich $z$ wischen diesen beiden Reactionsformen $z u$ wechseln," he is proposing an esoteric psychology, not a scientific method. Wundt insists that the 'subject' in psychological measurements must always be a skilled psychologist. Yet he writes on Thierseele! The investigator should, indeed, be a skilled psychologist, able to interpret the facts, but a psychologist with a theory to prove is not a good observer.

Every one who wishes to make psycho-physical time-measurements should read the article by $W$ undt and the letters in the same number of the Studien by Prof. Kraepelin and Dr. Merkel-not in order to accept as a matter of course the observations given-but in order to realize the need of observing and recording the changes in consciousness accompanying such experiments.

Prof. Titchener's discussion of sensory and motor reactions in Mind is more careful and judicial than is Wundt's. He sums up the 
evidence of ten researches and finds six favorable to the distinction and four more or less negative. Prof. Baldwin, however, seems to be counted on the wrong side, as he finds (in a publication later than the one quoted) the nature of the difference to. vary with the observer; and Prof. Titchener himself has found the distinction in less than half the cases he has tested. We. may conclude that the normal reaction-time of an observer can often be lengthened by directing him to fix his attention on the senseimpression, but it does not seem so evident that it can be shortened by directing him to fix his attention on the movement. The reaction-time is naturally lengthened and made more irregular when its automatic nature is disturbed; and from the experiments made in the Leipzig laboratory, it would seem that attending exclusively to. the sense-impression is more disturbing than attending exclusively to the movement. In daily life, however, the contrary holds; actions are executed more automatically when the attention is directed to the sense-impression-thus in throwing, catching or striking a ball, the more completely one can attend to the ball and forget the movement, the more efficient and quick is the movement. Indeed, in reaction-time experiments, when the stimulus is so strong as to compel the attention (as with painful electric shocks), the reaction-time is very short, which would seem conclusive against the extreme views of Lange and Wundt. That the difference between the times of sensory and motor reactions gives the time required to perceive the stimulus (Wundt and also Titchener in his earlier paper, Philos. Stud., VIII.), does not seem admissible to the present writer.

In the short paper by Prof. Titchener and Mr. Watanabe, attention is again called to the desirability of treating reaction-time experiments from the point of view of psychology. The observer's impression regarding the nature of the reaction is recorded. The writers conclude that in the case of sensory reactions introspection affords an adequate control, but is less trustworthy in the case of muscular reactions.

J. McK. C.

\section{JUDGMENT AND BELIEF.}

Glaube und Urtheil. W. JERUSALEM. Vierteljahsschirft für wissenschaftliche Philosophie. Vol. XVII, pp. 162-195.

Grundzüge der Logik. T. LIPPs. Hamburg u. Leipzig: Voss.

Principii di Logica Reale. N. R. D'Alfonso. Rome: 1894.

Appearance and Reality (passim). F. H. BRADLEY.

The Test of Belief. J. P. Gordy. Philosophical Review, May, 1894, 257.

Few states of consciousness, or psychoses, whether viewed from the psychological or from the epistemological standpoint, are 